\title{
Studies upon the effect of abrasive grain size on technological quality during the AWJ cutting of S235JR steel
}

\author{
Badania wpływu wielkości ziaren ściernych na jakość \\ technologiczną w procesie przecinania AWJ stali S235JR
}

\author{
SŁAWOMIR SPADŁO \\ TADEUSZ GAJEWSKI \\ DANIEL KRAJCARZ \\ ZBIGNIEW DRABIK *
}

DOI: https://doi.org/10.17814/mechanik.2017.11.160
The influence of the abrasive grain size on the technological quality of the intersection of non-alloy structural steel S235JR, is presented. The experiment was carried out on a high-pressure water-jet APW 2010BB abrasive cutting machine using the abrasive garnet $\# 80$ and $\# 120$. Studies included the assessment of intersection surface macrostructure: slit width, shape defects and surface roughness. Experiment has confirmed that the size of abrasive grains significantly influences the macrostructure of the intersection surface. Smoother cuts can be made with finer grains, but finer abrasive particles have less kinetic energy, leading to reduction in the erosion capacity of the water jet. The study was carried out at variable feedrate, therefore it was possible to determine the influence of the feedrate on the average square surface deviation. Increasing the feedrate resulted in a decrease in the entire width of the cut slit, which was especially noticeable in the lower cut zone of the workpiece.

KEYWORDS: steel cutting, abrasive water-jet cutting, technological quality of cutting

High-pressure water jet cutting technology is extremely versatile and can be used both for cutting hard materials and for those with low hardness [1].

Where the workpiece requires a high kinetic energy stream, an abrasive additive is used to intensify the erosion of the material [2-3]. As an intensifier of the erosion process, abrasive is usually used in the form of almandine granite, corundum and silicon carbide.

The most important advantages of abrasive water-jet cutting (AWJ) include [4-5]:

- no thermal effects during the cutting process,

- slight pressure force,

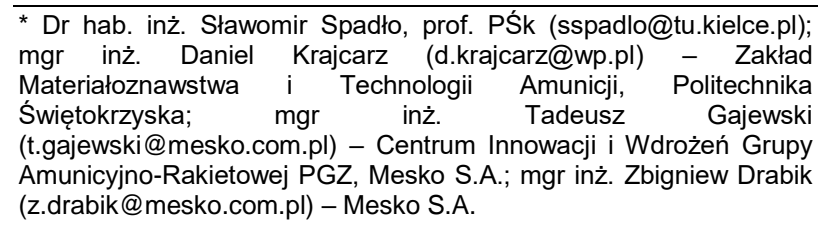

- relatively high precision of machining,

- occurrence of a narrow cutting slit.

Due to its wide range of machining applications, abrasive water-jet technology is a competitive alternative to commonly used cutting methods [6].

The technological quality [7-8] obtained in the process of cutting is a result of several independent variables, which are parameters of the cutting process [9-11]. These parameters can be divided into the following groups:

- hydraulic (supplying pressure, diameter of the jet, power of the jet),

- abrasive properties (type of abrasive, grain size, grain shape, abrasive flow rate),

- technological parameters (feedrate, cutting head distance from the workpiece, geometry of water and molding nozzle).

Understanding the influence of particular parameters of the process on technological quality of the obtained intersection area will allow to develop the model of the cutting process of examined material.

\section{Methodology of research}

The aim of the experimental tests was to determine the influence of the abrasive grains and the feedrate on technological quality of the cut surface - for example S235JR structural alloy steel having a thickness of $3 \mathrm{~mm}$. This species is a common construction material.

Table I presents chemical composition of the standard test material.

TABLE I. Chemical composition of S235JR steel [12]

\begin{tabular}{|l|l|}
\hline \multicolumn{1}{|c|}{ Element } & \multicolumn{1}{|c|}{ Content, \% } \\
\hline $\mathrm{C}$ & 0.20 \\
\hline $\mathrm{Mn}$ & 1.40 \\
\hline $\mathrm{P}$ & 0.035 \\
\hline $\mathrm{S}$ & 0.035 \\
\hline $\mathrm{N}$ & 0.012 \\
\hline $\mathrm{Fe}$ & rest \\
\hline
\end{tabular}


The tests were carried out with a variable feedrate ranging from 50 to $300 \mathrm{~mm} / \mathrm{min}$. The abrasive used in the cutting process was a garnet of grain size \#80 and \#120. It is a mineral of natural origin, belonging to the family of silicates. Its hardness is up to 8 in the Mohs scale, the specific mass is $4.2 \mathrm{Mg} / \mathrm{m}^{3}$ and the bulk density is $2.34 \mathrm{Mg} / \mathrm{m}^{3}$ [13]. Fig. 1 shows the view of grains \#80 and \#120. Photographs were made using JEOL JSM-7610F field emission scanning electron microscope.

Table II presents constant parameters of the cutting process adopted for the purpose of the experiment. The research was carried out on APW 2010BB machine.

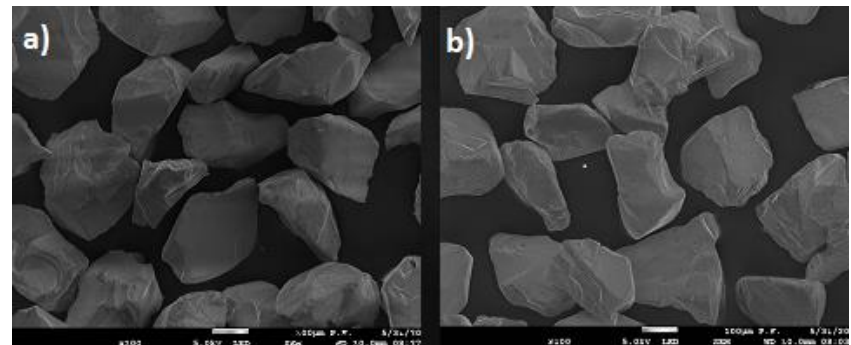

Fig. 1. Microphotograph of abrasive grains: a) \#80; b) \#120

TABLE II. Parameters of the cutting process

\begin{tabular}{|l|c|}
\hline \multicolumn{1}{|c|}{ Parameter } & Value \\
\hline Water pressure, MPa & 280 \\
\hline Quantity of dozed abrasive, g/s & 4.0 \\
\hline Distance nozzle from the workpiece, mm & 2.0 \\
\hline Diameter of the water nozzle, mm & 0.30 \\
\hline Diameter of the forming nozzle, mm & 1.02 \\
\hline Length of the forming nozzle, $\mathrm{mm}$ & 75 \\
\hline
\end{tabular}

Cut width and shape errors studies were performed using the O-Inspect multi-sensor coordinate measuring machine at the 12-fold telecentric lens magnitude. Talysurf $\mathrm{CCl}$ Lite optical profiler was used for measurements of surface geometric parameters. This device is used for making optical, contactless measurements and analyzing the surface geometry. The profilometer is capable of joining the measurement results. The results were analyzed in TalyMap Platinium software.

\section{Study results}

In order to evaluate the geometry of the intersection slit, a series of slit width measurements were performed in the upper $\left(w_{t}\right)$ and lower cutting zone $\left(w_{b}\right)$. Sample shapes of intersection slits with marked measurement location are shown in fig. 2.

Measurements of the width of the intersection slits were made at a short distance from the edge of the cut material. Measurement at the very edge would be faulty due to:

- rounded corners at the inlet of the jet in cut material, - burning at the exit of the jet from cut material.

Grain size and feedrate were the variables used in the study. The results of the measurements are shown in the diagram (fig. 3).

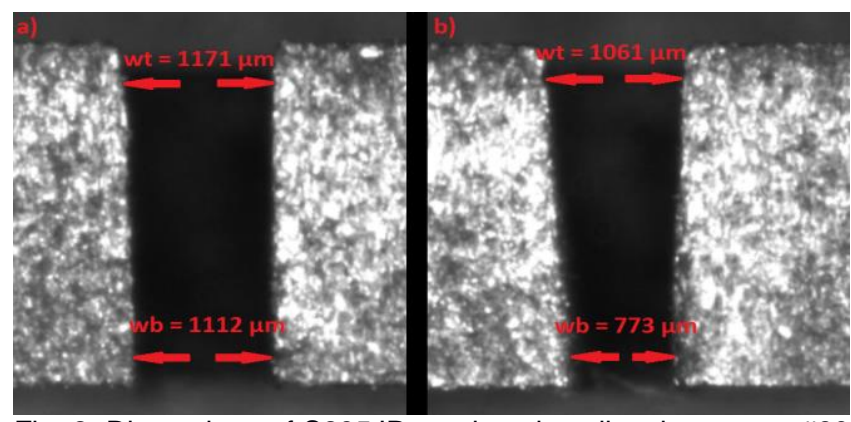

Fig. 2. Dimensions of S235JR steel cutting slit using garnet \#80 for feedrates: a) $50 \mathrm{~mm} / \mathrm{min}$, b) $300 \mathrm{~mm} / \mathrm{min}$

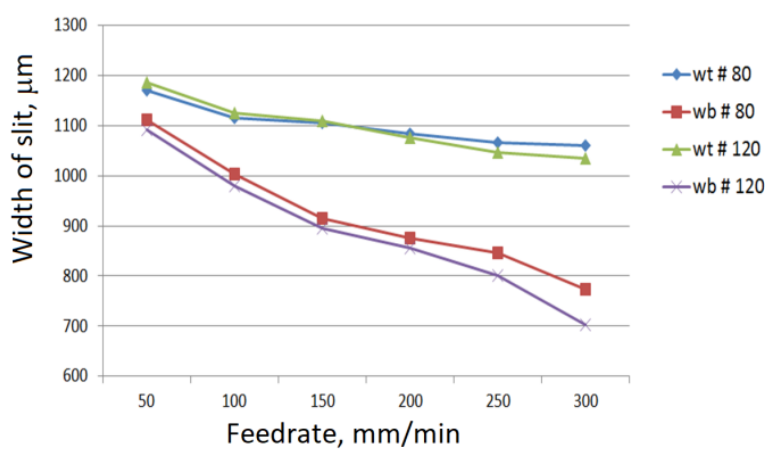

Fig. 3. Influence of feedrate on the width of the upper $\left(w_{t}\right)$ and lower $\left(w_{b}\right)$ cutting slits depending on the size of abrasive grains used

After analyzing the measurement results in the upper zone $\left(w_{t}\right)$ in the examined area, no significant influence of the abrasive grain size on the slit width after cutting was found. Although the gap obtained with garnet \#80 is generally slightly larger - in the order of a few to several micrometers (this is visible at 250 and $300 \mathrm{~mm} / \mathrm{min}$ ), the differences are minor. It is assumed that due to the larger grain size of garnet \#80 (and thus higher kinetic energy), the cut gap may be slightly wider.

In the case of measurements in the lower zone $\left(w_{b}\right)$, a much more pronounced tendency to taper the slit was observed with increasing the feedrate. As a result, the intersection gap forms a "V" shape. This is related to the phenomenon of falling kinetic energy of the jet along with the penetration of the cutting jet into the cut material. The use of smaller abrasive grains reduces the erosion potential of the abrasive jet, which is evident with increasing feedrate.

In order to evaluate the geometry of the intersection more fully, the 3D surface geometry was measured. The average square surface deviation $(S q)$, defined as the standard deviation of the surface unevenness, was chosen as the test variable. This method of analysis results from the fact that the parameters marked with the letter "S", which characterize the geometrical structure of the surface in $3 \mathrm{D}$, allow for a more reliable evaluation of the surface with respect to point roughness. Detailed topographic maps of surface geometry using TalyMap software for variable feedrates and different sizes of abrasive grains are shown in fig. 4 and fig. 5 .

In abrasive water-jet machining, the deterioration of the roughness results from the occurrence of two different phenomena shaping the quality of the intersection. In the area of the surface, there is the phenomenon of sliding wear, therefore the roughness is relatively stable and reaches a small value. In the impact zone, there is already a significant deterioration in the surface quality and, consequently, an increase in the 
roughness value. The differences in the flow of abrasive water-jet with the workpiece depending on the depth of cut are visible in the images presenting the topography of the surface. In the areas where the jet is not visible, the direction of the traces is not visible. In the output zone of the jet, the AWJ-specific grooves, which are the remainder of the direction of the principal abrasive grain, are observed, the track of which, along with the increase in the feedrate, is curved.

Fig. 6 graphically shows the effect of abrasive grain size and feedrate on the average square values of the entire intersection.

Based on the analysis of results, it can be concluded that the size of abrasive grains significantly influences on the mean square deviation of the surface. Throughout the range tested, the $S q$ parameter was higher each time for the surface obtained with larger grains of abrasive. Significant differences are also observed for higher feedrates - in this case, a similar trend is observed despite a much higher decrease in kinetic energy of the abrasive jet for the lower granulation of abrasive.

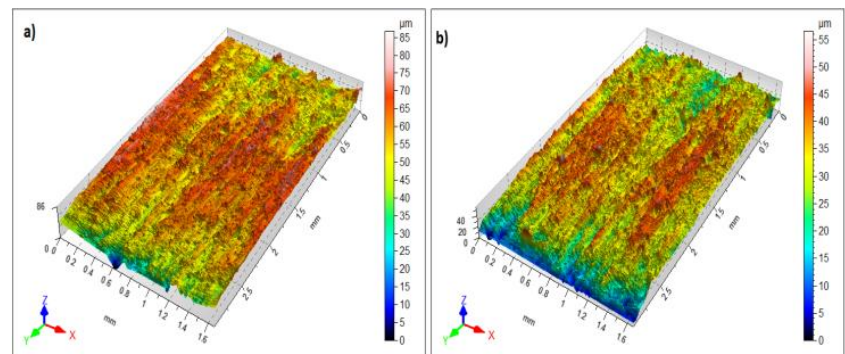

Fig. 4. The isometric image of the intersection of S235JR steel cut at feedrate $50 \mathrm{~mm} / \mathrm{min}$ and using abrasive: a) garnet $\# 80, b$ ) garnet \#120

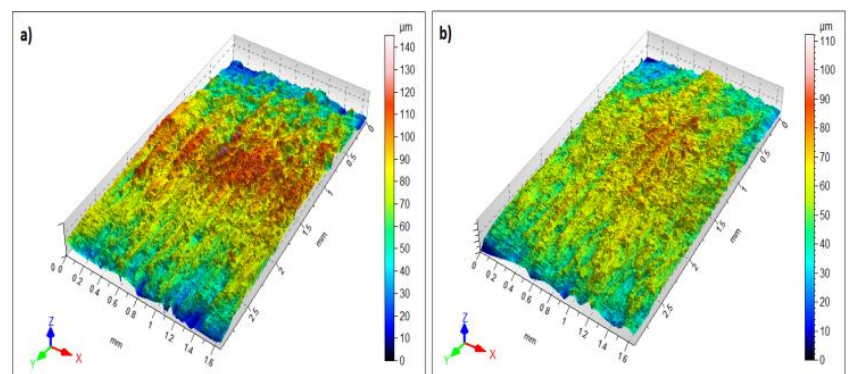

Fig. 5. The isometric image of the intersection of S235JR steel cut at a feed rate of $300 \mathrm{~mm} / \mathrm{min}$ and using abrasive: a) garnet $\# 80$, b) garnet \#120

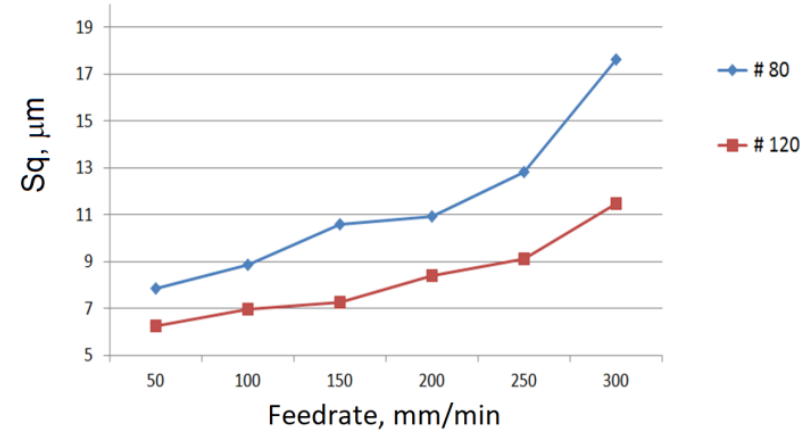

Fig. 6. Influence of feedrate on average square surface deviation $(\mathrm{S} q)$ depending on the size of applied abrasive grains

\section{Conclusions}

Based on the results of the research, it can be concluded that the technological quality of the intersection of the workpiece by means of abrasive water-jet is dependent on the parameters of the cutting process.

The size of abrasive grains used in the cutting process significantly influences on the macrostructure of the intersection. Smooth cuts can be made with a smaller average square deviation value of the surface.

The cut gap in the case of using a lower-granulated abrasive takes the form of the letter "V". This phenomenon is aggravated by the increase in feedrate and is especially visible in the lower cutting zone. This is related to a faster decrease in kinetic energy of the jet.

As the feedrate increases, the cutting capacity of the abrasive water-jet decreases. Smaller amount of abrasive grain affects the machined surface, and additionally with the penetration of the material into the cut material, the micro grinding process of abrasive grains is replaced by other mechanisms of material destruction, resulting in deterioration of the technological quality of the intersection.

It should be kept in mind that surface parameters average the results of measurements for the entire surface and allow for a general trend. Therefore, the local values of the parameter in the case of average square deviation of the selected profile may considerably vary. This parameter assumes higher values for profiles that are closer to the outlet of the jet from the slit of the cut material.

\section{REFERENCES}

1. Borkowski J., Borkowski P. „Przecinanie zawiesinową strugą wodno-ścierną wytwarzaną metodą BORJET”. Inżynieria Maszyn. 13 (2008): pp. 104-112.

2. Sutowska M. „Wskaźniki jakości procesu cięcia materiałów strugą wodno-ścierną". PAK. 57 (2015): pp. 535-537.

3. Hlavac L. "Investigation of the abrasive water jet trajectory curvature inside the kerf". Journal of Materials Processing Technology. 209 (2009): pp. 4154-4161.

4. Kulekci M.K. "Processes and apparatus developments in industrial waterjet applications". Journal of Materials Tools \& Manufacture. 42 (2002): pp. 1297-1306.

5. Wantuch E., Kudelski R., Nieciąg H. "Dependency of the technological quality of elements made from an aluminum alloy on their shape in the water jet machining". Journal of Machine Engineering. 13, 4 (2013): pp. 35-46.

6. Mazurkiewicz A. „Czynniki wpływające na jakość powierzchni stali po cięciu strumieniem wodno-ściernym". Inżynieria Materiałowa. 5 (2008): pp. 1-4.

7. Kudelski R., Zagórski K., Wantuch E., Reben M. „Warstwa wierzchnia elementów wycinanych wysokociśnieniowym strumieniem wodno-ściernym”. Mechanik. 8-9 (2015): pp. 221-226. 8. Spadło S., Młynarczyk P., Łakomiec K. "Influence of the of electrical discharge alloying methods on the surface quality of carbon steel". International Journal of Advanced Manufacturing Technology. 89 (2017): pp. 1529-1534.

9. Hlavac L., Krajcarz D., Hlavacova I., Spadło S. "Precision comparison of analytical and statistical-regression models for AWJ cutting". Precision Engineering. ttps://doi.org/10.1016/j. precisioneng.2017.05.002.

10. Matuszewski M., Oborski I.L., Styp-Rekowski M. „Efektywność obróbki wodno-ściernej - wybrane zagadnienia". "Mechanik. 4 (2015): pp. 52-55.

11. Chithirai Pon Selvan M., Mohana Sundara Raju N. "Assessment of process parameters in abrasive waterjet cutting of stainless steel". International Journal of Advances in Engineering \& Technology. 1, 3 (2011): pp. 33-40.

12. PN-EN 10025-2:2007 Wyroby walcowane na goraco ze stali konstrukcyjnych - Część 2: Warunki techniczne dostawy stali konstrukcyjnych niestopowych.

13. Garnet Polska, http://garnet.com.pl [access: 28.05.2017]. 